Marquette University

e-Publications@Marquette

English Faculty Research and Publications

English, Department of

$1-1-2000$

Gothic Drama as Nationalistic Catharsis

Diane Hoeveler

Marquette University, diane.hoeveler@marquette.edu

Published version. The Wordsworth Circle, Vol. 31 (2000): 169-172. Publisher Link. (C) 2000 Boston University Editorial Institute. Used with permission. 


\section{Gothic Drama as Nationalistic Catharsis}

\section{Diane Long Hoeveler Marquette University}

In Specular Politics (1993), Paula Backsheider suggested that gothic drama is "the earliest example of ... mass culture ... an artistic configuration that becomes formulaic and has mass appeal, that engages the attention of a very large, very diverse audience, and that stands up to repetition, not only of new examples of the type but production of individual plays" (150). But what is repeated in the gothic drama, and how were those repetitions-often excessive, hyperbolic, blatantly fantastical-manipulated so that the genre gained mass appeal? This essay examines the social and political ideologies that are explicit in the major gothic dramatic adaptations of the most popular gothic novels of the period: Lewis's "Castle Spectre," a loose adaptation of Walpole's Castle of Otranto; Siddons' Sicilian Romance, an adaptation of Radcliffe's novel of the same title; and Boaden's "Fountainville Forest," another adaptation based on Radcliffe. The essay will conclude by focusing on perhaps the least familiar of Boaden's gothic dramas, his Cambrio-Britons, a drama that, like Wordsworth's The Borderers (1796; 1842), is complicitous in constructing the new British nationalistic character that Burke was codifying in his prose.

Curiously, all of these works use a ghost, a female ghost who in three of them embodies both a socially conservative message and a direct political warning to the protagonists of the drama, and, by extension, to the audience. Examining these dramas not simply as inferior adaptations intended for a mass audience, one sees that each participates in the ongoing national debate about the proper role of the monarchy, the threat of violent revolution, the shock of sudden class transformation, the anxiety of changing gender roles within the family structure, and, finally, the construction of a newly nationalistic British empire that sought to justify its absorption of Ireland, Scotland, and Wales.

As Jeffrey Cox has pointed out in relation to Romantic drama and the French Revolution, when history itself becomes theatrical, theater responds by "translating the representation of revolt from history to myth" (241). Is gothic drama, as Peter Brooks observed about melodrama, essen- tially conservative, a means of reinstating social and political order (15), or can it be understood as a species of what Hayden White has called "anarchistic," calling for a dissolution of contemporary institutions in order to reclaim a more humane community that existed sometime in the past (24-5)? Each of these dramas is not simply politically conservative, as has often been argued, but rather constructs a distant past that the play reshapes as redeemable through the elimination of corrupt aristocrats. Each play presents a political and social warning to the monarchy: reform or be overthrown by violence, which constitutes an anarchist message. Under the spectre of the French Revolution these works introduce middle-class characters who embody the best of what Britain must become if it is to avoid the violent and chaotic fate of France. The dramas attempt to mediate between classes, races, and genders that were at odds over the shape and power structure of the evolving bourgeois society. The dramas function, then, as cathartic forms, public rituals in which the middle class haunted itself with its own act of imagined, fantasized revolution, usually depicted as some form of matricide or fratricide. In a series of what might be seen as social and political morality plays, the middle class audience encountered its own mythology of origins, its own "Hyperion"-like creation of a new order built on the backs of an aristocracy that simply did not deserve to survive.

As Robert Miles has noted, those involved in the invention of the gothic embraced the hieratic function of keeping alive the sacred mementoes of the race. But ideological conservatism intersected with the democratic nature of artistic production for the masses, creating what Foucault has called a "site" of "power/knowledge" at odds with itself. As a site of opposing strategies, the gothic drama became a "hazardous play of dominations" seeking to compose a coherent position amid rapid social, historical, and cultural transformations. It is, according to Miles, in the moments of slippage and discontinuity that the ideological business of the gothic aesthetic is most apparent (32). For him, the gothic aesthetic incorporates an idealized national identity together with a myth of origins (50). 
This position is very close to James Watt's in Contesting the Gothic (1999). For Watt, the 1790s through the early 1800 s were dominated by what he calls the creation of "Loyalist Gothic" romances. He sees these works as reactions to Britain's defeat in America in that they portray a proud heritage of military victory played out within a moral and political agenda. Set around a real castle in Britain, these works present a stratified yet harmonious society, use real historical figures from the British military pantheon (Arthur or Alfred were particular favorites), and consistently depict the defeat of effeminate or foreign villains. Loyalist gothics are structurally bound to depict an act of usurpation which is always arighted, often through the supernatural agency of a ghost (7).

One example, according to Watt, is William Godwin's early romance Imogen (1748), set in prehistoric Wales and idealizing a "pure, uncorrupted society in the mythical past as a bulwark against the hegemonic forces of English imperialism" (45). Unlike Gray's "The Bard," Godwin's novel hints that the act of trespass and usurpation made when Edward I conquered Wales could be reversed. Because "Great Britain," in other words, could only come into being through acts of usurpation of property and title condoned by the public, these acts were played out in veiled form on the gothic stage, where women were usually powerless pawns of powerful and corrupt aristocrats. The act of forming itself into a nation was, in effect, the real trauma that was occurring in England, enacted vicariously on the London stage for all to witness and accept.

The quest for an idealized national identity, however, needs to be set into the still larger historical context in which popular gothic dramas were produced. England and Scotland signed the Act of Union in 1707, ending years of hostility and territorial skirmishing. But this document was, as Tom Nairn has pointed out, a largely "patrician bargain" because the signers were mostly aristocrats (136f). The task of the next hundred years was to imaginatively separate and differentiate England and Scotland in the popular consciousness-and that became largely the province of Romantic literature's cultural work. As Benedict Anderson noted, one of the ways a country builds a sense of its own nationality is to imagine itself as antique (and thus the medievalism in Keats, Coleridge, Shelley, Wordsworth, and Walter Scott). But an equally effective way to build the consciousness of a nation state is to construct a local adversary on the very borders in order, as Anderson points out, to create a clearly defined sense of space, a newly sacred territory potentially threatened by lawless of crude infidels (xiv). Scotland, Wales and Ireland, became for the Romantic consciousness such border communities, the "others" that England had to separate from, master and suppress, dominate and oppress in order to forge its own sense of amalgamated nationhood.

Matthew Lewis's The Castle Spectre (1797) was the most popular gothic drama performed in England in the late
1790 s, based on Horace Walpole's The Castle of Otranto, although the setting and characters differ in several important ways. The contested castle has moved from Italy to the border of Wales and England during the 10th century. This shift both localizes the place and makes the gothic a British phenomenon to explore British anxieties about nationhood, borders, and outsiders-women and blacks-clamoring to breech the moats that an aristocratic and male-dominated culture had constructed for itself. Angela, the besieged gothic heroine in this drama, is aided in her struggle against her evil uncle Osmond by a group of social outcasts: a fool, a gluttonous friar, servants, and finally, the ultimate outcast, her murdered mother's ghost. Osmond had murdered Evelina, his sister-in-law, in a botched attempt to kill the entire family of his eldest brother so that he could usurp the estate. At the drama's climatic moment (Osmond's second attempt to murder his brother Reginald), the ghost of Evelina appears and throws herself between the two brothers. This action so startles Osmond that he drops his sword and Angela "suddenly springs forward and plunges her dagger into Osmond's bosom." It is Angela who calmly steps forward and gives instructions for the care of her wounded father, cleaning up the mess made by the warring sons.

The same matter-of-fact presentation is made of the black servant Hassan and the Indian Saib. It is as if Lewis has invited the empire's colonial lackeys home for dinner, thereby highlighting the incongruity of Britain's involvement in the slave trade and Indian expeditions. These recent historical realities are transplanted back into the 10th century, suggesting an analogy between the treatment of women and the treatment of slaves.

Even more fraught with contradictory ideological baggage is Henry Siddons' 1794 "Sicilian Romance; or the Apparition of the Cliff," which also uses the device of a daughter saved by what appears to be her mother's ghost. This drama undercuts the supernatural element by having the mother imprisoned by her evil husband so that he can marry a young and wealthy heiress. Her ghostly appearances at night, seen by many around the cliff where she is imprisoned, are resolved when the daughter Julia unbars a door and her mother magically returns, as if from the dead. When the evil Ferrand discovers the mother and daughter's reunion, he resolves to kill them both himself. As he rushes on them, the mother pulls a dagger and says, "Advance not, on your life! / Spite of thy cruelty, I love thee still, / Still live in hopes to charm thy savage soul, / And melt it into tenderness and love" (III.iv). This melting never occurs, and the father cannot be assimilated into the restored family that sings the praises of the king in the closing scene. A drama that has presented the ruling patriarch of this tiny principality as a ravening, lustful madman concludes, then, with a song in praise of George III.

Boaden's Fountainville Forest, based on Radcliffe's Mysteries of the Forest, is relevant here, as is his later gothic-histori- 
cist drama The Cambrio-Britons, his unsuccessful bid to be taken seriously as a dramatist in the manner of Shakespeare. Fountainville Forest (1794) presents a mysterious ghost, simply called a "phantom." As Adeline, the heroine, reads her murdered father's journal, the phantom speaks on three occasions to confirm her worst fears, that, yes, her uncle was the usurping murderer of his own brother and now, incestuously, pursues her, his niece. The phantom, although cowled and ambiguous, represents the heroine's dead father, so that the crime here is not matricide, as it becomes in Lewis, but fratricide. Dynastic intrigue, warring brothers, and the eroticized daughter-figure are all stock devices by 1794, but their ritualistic embodiment on stage raises the questions: what cultural work is being performed? Why does a male ghost, the dead father, haunt this play rather than the dead mother? Is the state as well as the family under social and political siege? Rapid transformations in the family structure had caused even the patriarch, it would appear, to tremble in his own domicile.

Boaden (1762-1839) wrote eight dramas during his lifetime, but is best known for his five theatrical biographies, notably the Life of John Philip Kemble, a primary source for materials on the late 18th and early 19th century theatre. Following his adaptations of Radcliffe's novels, Boaden wrote Cambrio-Britons, an historical drama in the style of Shakespeare, first performed on July 21, 1798, at the Haymarket. A play that depicts the conquest of Wales by England in the 13 th century, the drama was relevant to the contemporary war against France. As Boaden noted in his Life of Kemble, he used the play to meet "the menaces of foreign invasion, in the year 1798, with patriot sentiment." Written at the height of invasion fever, as Cohen observed, the play opened one month before France actually attempted to invade (xxvi). In the same biography Boaden explained that dramas should not be the venue for party politics, but that the theater would be "deficient in its noblest duty, when it inspires no ardour against an invading enemy" ("Preface" to Cambrio-Britons). Further, Boaden thought that the play would inspire every one in the audience to "thank" him for "seeking to sustain the independence of his country" (qtd in Cohen, xxvii). But he misunderstood, according to Cohen, that the sympathies of the play are with the Welsh, who are struggling to maintain their independence against the oppressive and corrupt English, led by King Edward in 1282. The drama's analogy actually works against England, aligning the 1798 England with France, an unlawful and greedy usurper of land not its own. Like Lewis's depiction of the African slave Hassan, the gothic is fissured, the exterior working against and undercutting the interior of the argument that the drama actually makes through both the action and the resolution.

Beyond the confusing and contradictory political allegory, Boaden uses a female ghost, just as Lewis does. In this drama the dead mother of Prince Llewellyn and his traitorous brother David appears on the altar of a church, urging her two warring sons to reconcile and join to fight their com- mon English enemy. This ghost garnered the most attention for the play, leading critics to accuse Boaden of plagiarizing Lewis's Castle Spectre. In defense of himself, Boaden pointed out that if anyone were the plagiarist, it was Lewis, whom he accuses of stealing Boaden's earlier ghost in The Fountainville Forest ("Preface" to Cambrio-Britons).

Boaden's play begins with an atmosphere of suspicion and paranoia, as every soldier, including Llewelyn's own brother, is suspected of disloyalty to the preservation of Welsh independence. As one Welsh soldier remarks after accepting a bribe to change allegiance, "We have now no safety but in the conqueror's mercy" (I.i.8). Interestingly, one of the first figures to speak in the drama is the Irish minstrel, O'Turloch, who entertains the Welsh royalty with a song about King Arthur, said to have been imported by Scottish minstrels. The song concerns a woman who pleads with Arthur to avenge her against a knight who has raped her, a situation that parallels Llewelyn's wife who has been pursued aggressively and incestuously by David, his twin brother. The presence of Arthur, the last Celtic King, became a stock device in a number of Loyalist gothic texts that were trying to recall an idealized Celtic golden age, pre-Norman, pre-aristocratic, and pre-Hanoverian. But the bard, according to Katie Trumpenet, in Bardic Nationalism, "For nationalist antiquaries, . . . is the mouthpiece for a whole society, articulating its values, chronicling its history, and mourning the inconsolable tragedy of its collapse. English poets, in contrast, imagine the bard (and the minstrel after him) as an inspired, isolated, and peripatetic figure. Nationalist antiquaries read bardic poetry for its content and its historical information; their analyses help to crystallize a new nationalist model of literary history. The English poets are primarily interested in the bard himself, for he represents poetry as a dislocated art, standing apart from and transcending its particular time and place" (6). For Trumpener, the contrast points to the collapse of Celtic clan culture (in Ireland, Wales and Scotland) and the rise of a form of individualism and literary commodification in England that eventually triumphed over the earlier oral-based culture.

The high point of the drama occurs in a gothic chapel at the shrine of the mother, Lady Griffyth. Informed by his wife Elinor that his brother stills pursues her and has traitorously thrown in with the English invader, the "haughty Edward," Llewellyn confronts his brother before their mother's tomb. As they each draw swords to settle their longstanding rivalry, the ghost of their mother suddenly appears and speaks: "Forbear!" As the swords magically fly out of the brothers' hands, their ghostly mother goes on to pronounce: "Have I not loved you?-Be peace between you! / Confirm it at the altar!" After the two men kneel and embrace, their mother gives her blessing and the chorus of spirits declares: "Grateful the voice that bids your hatred cease, / A mother's mandate of fraternal peace." In the elaborate stage directions, the funereal dress falls off the mother and "her figure seems glorified; and through the opening window she is 
drawn, as it were, into the air, while music, as of immortal spirits, attends her progress. The brothers gaze silently after the vision" (II.v.58). This miraculous disrobing and ascent appears to replay aspects of the bleeding nun legend in which a murdered woman can have no eternal peace until she is avenged and buried in hallowed ground. Boaden's adaptation of the legend suggests that the mother cannot ascend to Heaven until her two sons are reconciled, but as a political allegory, the image is loaded with contradictory freight. Reconciled, the brothers fight the tyrant Edward to a standoff. After much singing, Edward recognizes Llewellyn as the Prince of Wales, and declares to him, "Be my friend/ My nearest, best ally; and, in her perils, / Let England ever find her warmest champion, / Her grace, her glory, in the prince of Wales!" (III.iv.88).

Politically, the drama appears to affirm a reconciliation of rival claims to land through the appearance of a beneficient maternal presence, ghostly but powerful, absent but present. The dead mother, rising from her grave to demand cooperation from the warring brothers, suggests at least the avatar of Elizabeth I, the dead but undead political mother, wise, skillful, and infinitely diplomatic in the ways of avoiding direct conflict and open warfare. Is it possible that the anxieties about the condition and suitability of the heir to George III's throne precipitated the dynastic emphasis in popular gothic dramas? Beyond nationalistic debates or fear of French invasions, British gothic dramas expressed tangible fear that the House of Hanover had come to an inglorious end in all but name? The infant daughter of George IV, Princess Charlotte (b. 1796), appeared to be a fragile hope for the British monarchy. In order to buttress her potential status, the spectre of the last great female queen appears, disguised as a female ghost haunting the disputed borders of Wales and England, Scotland and England, England and its own colonies abroad. The intense mourning that gripped England when Charlotte died in childbirth a mere twentyone years later found expression in, as Behrendt documents, a huge "Charlotte industry," poems, broadsides, and souvenir trinkets (122ff). If her death caused such intense, hyperbolic, and theatrical displays of mourning, might it not be conjectured that her birth was also the subject of a certain amount of concern?

The female ghost who appears in these dramas also suggests an intense uneasiness about the role and nature of women in the coming century. That these ghosts are mothers, murdered, displaced, separated from their children, also suggests a deeply conservative agenda. Women, it would seem, are being properly positioned on the stage in their maternal roles, because the gothic visual aesthetics presupposes a masculine subject dazzled not simply by an eroticization of the female body but also by her maternal function. (I am thinking in particular here of Lewis's ambivalent presentation of Mathilda/Rosario in The Monk in contrast to Melmoth the Wanderer's presentation of Isidora). In addition, the aesthetics of the sublime presupposes a female subject-position disciplined through the presence of the male gaze (Miles 51) - or what I would call the bourgeois gaze. The mass audiences that flocked to the gothic dramas remembered the ghost scenes because those were the most dramatic, most frightening, most uncanny appearances of either dead mothers or dead fathers on the stage. In a nation struggling to consolidate land it had only recently claimed, as well as land it was claiming abroad on a tenuous basis at best, the political guilt and social anxiety must have been intense. At the same time that the national borders were viewed as precarious and diffuse, so were the psychic ones. The ghosts haunting the gothic stage were the ghosts of empires lost and found, mothers and fathers and children displaced and replaced, used and abused.

\section{WORKS CITED}

Anderson, Benedict. Imagined Communities: Reflections on the Origin and Spread of Nationalism. Rev. ed. 1991; Backsheider, Paula. Spectacular Politics: Theatrical Power and Mass Culture in Early Modern England. 1993; Behrendt, Stephen C. Royal Mourning and Regency Culture: Elegies and Memorials of Princess Charlotte. 1997; Brooks, Peter. The Melodramatic Imagination. 1976; Cohen, Steven, ed. The Plays of James Boaden. 1980; Cox, Jeffrey. "Romantic Drama and the French Revolution." In Revolution and English Romanticism. Ed. Keith Hanley and Raman Selden. 1990; Lewis, Matthew. "The Castle Spectre." In Seven Gothic Dramas: 1789-1825. Ed. Jeffrey Cox. 1992; Miles Robert. Gothic Writing 1750-1820: A Genealogy. 1993; Nairn, Tom. The Break-Up of Britain. 1977; Trumpener, Katie. Bardic Nationalism: The Romantic Novel and the British Empire. 1997; Watt, James. Contesting the Gothic: Fiction, Genre and Cultural Conflict, 1764-1832. 1999; White, Hayden. Metahistory. 1973. 